\title{
Nawacita, Pancasila, dan Ideologi Politik Pembangunan Nasional
}

\author{
Lestanta Budiman', Hastangka²
}

\footnotetext{
${ }^{1}$ Pusat Studi Pancasila, Universitas Pembangunan Nasional Veteran Yogyakarta, lestantabudiman@upnyk.ac.id

${ }^{1}$ Pusat Studi Pancasila, Universitas Pembangunan Nasional Veteran Yogyakarta, hastangka@gmail.com
}

INFO ARTIKEL
Riwayat Artikel:
Diterima: 25 September
2020
Disetujui: 30 September
2020

\section{Kata Kunci:}

Nawacita

Pancasila

Ideologi

Politik

Pembangunan

\section{A. LATAR BELAKANG}

\section{ABSTRAK}

Abstrak: Pembangunan suatu bangsa tidak lepas dari ideologi politik yang diletakkan. Ideologi politik ini dapat berpengaruh dalam mengarahkan dan membentuk paradigma pembangunan nasional. Di Indonesia, politik pembangunan nasional selalu dipengaruhi oleh ideologi dan politik penguasa. Penguasa pada setiap zaman atau periode pemerintahan memiliki dasar ideologis dan politik yang unik dan khas dalam menjalankan pemerintahannya. Studi tentang pembangunan selama ini memang tidak terlalu banyak membahas peran dan pengaruh ideologi dan politik di dalamnya. Studi pembangunan yang berkembang selama ini bergerak pada tiga arus utama yaitu ekonomi, lingkungan, dan tata ruang wilayah atau tata ruang kota. Pembahasan tentang paradigma pembangunan atau pengarusutamaan pembangunan merujuk pada dua posisi yaitu posisi global, dimana peran global mengarahkan paradigma pembangunan yang selama ini berkembang di bebagai negara negara di dunia. Kemajuan negara negara yang memiliki standar hidup dan ekonomi yang tinggi dapat mempengaruhi paradigma dan model pembangunan yang ada di seluruh kawasan atau benua. Penelitian ini bertujuan untuk mendeskripsikan dan menggali garis ideologi dan politik yang diletakkan oleh pemerintah dalam membangun gagasan pembangunan nasional yang berkeadilan sosial melalui konsepsi Nawacita dan Pancasila. Metode yang digunakan dalam penelitian ini menggunakan pendekatan kualitatif. Analisis data yang digunakan dalam penelitian menggunakan interpretasi, analisis kebijakan, dan korelasi. Data yang digunakan berupa buku teks, jurnal, laporan ilmiah, dan peraturan perundang undangan. Hasil penelitian ini diharapkan dapat memperlihatkan relasi antara Nawacita, Pancasila dalam praktek ideologi politik pembangunan.

Abstract: : The development of a nation is inseparable from the political ideology laid down. This political ideology can influence in directing and shaping the paradigm of national development. In Indonesia, the politics of national development has always been affected by the authorities' ideology and politics. The police in each era or period of government has a unique and unique ideological and political basis in carrying out their government. The study of development has not discussed too much the role and influence of ideology and politics in it. Development studies that have developed so far are engaged in three main currents: economy, environment, and regional or city spatial planning. The discussion of the development paradigm or the mainstreaming of development refers to two positions, namely the global situation, where the global role directs the development paradigm that has been developing in various countries in the world. Countries with high standards of living and economy can influence the development of paradigms and models that exist in all regions or continents. But a government that has not been fortunate or is still in the process of progressing towards the goals and objectives of the state tries to put its development paradigm on two legs. On the first foot, try to use the prescription of a global development paradigm. On the other hand, it uses the development paradigm, which is owned by the nation itself with the ideological and political lines laid by the authorities. In Indonesia, the idea of the ideology and politics of national development in the context of President Jokowi's administration spread an interesting ideological and political line, Nawacita. Nawacita is an ideal set forth in 9 agendas that are used as a reference and state ideological direction. This nawacita needs to be seen in the framework of national development. This study aims to describe and explore the government's ideological and political lines in building the idea of national development with social justice through the conception of Nawacita and Pancasila. The method used in this study uses a qualitative approach. Analysis of the data used in research uses interpretation, policy analysis, and correlation - the data used in the form of textbooks, journals, scientific reports, and legislation. This study's results are expected to show the relationship between Nawacita, Pancasila in the practice of political development ideology.
Wacana ideologi dan politik pembangunan menarik untuk menjadi pembahasan dan kajian di Indonesia. 
Sejak paska reformasi tahun 1999 dinamika kehidupan sosial dan politik di Indonesia banyak diwarnai dengan berbagai polemik seputar ideologi dan politik tentang arah dan tujuan negara Indonesia paska orde baru. Ideologi dan politik yang berkembang paska reformasi telah banyak berpengaruh dalam tatanan kehidupan bernegara khususnya pembangunan sistem politik dan sosial di Indonesia. Perubahan pembangunan sistem politik di Indonesia sejak paska reformasi sangat nampak dengan adanya desentralisasi dan distribusi kewenangan atau kekuasaan yang dulunya terpusat (sentralistik), dianggap oleh kelompok reformis sebagai bentuk pemerintahan otoritarian. Pemerintah otoritarian merupakan sistem pemerintah yang dianggap kurang demokratis atau pemerintah yang berpijak pada orientasi pembangunan politik kekuasaan, kemudian bergeser menjadi sistem pemerintahan yang memiliki check and balances dalam berbagai aspek.

Dampak dari reformasi memunculkan berbagai lembaga negara baru yang bertujuan untuk memberikan keseimbangan dan pengawasan terhadap jalannya sistem pemerintahan dan politik seperti Mahkamah Konstitusi (MK), Komisi Yudisial (KY), Komisi Pemberantasan Korupsi (KPK), dan Komisi Ombdusman. Perubahan yang nampak lebih jelas ialah sistem pemilihan umum yang dikembangkan mulai dari pemilihan kepala daerah sampai dengan presiden dipilih langsung oleh rakyat. Dalam konteks partai politik juga berkembang banyak partai politik baru bermunculan mengikuti kontestasi untuk mendapatkan kursi di parlemen dan kekuasaan di eksekutif.

Dalam aspek ideologi dan politik pembangunan juga menarik untuk dilihat. Perubahan mendasar yang terjadi terkait wacana ideologi dan politik pembangunan Indonesia paska reformasi dapat dilihat dari dua aspek yaitu pertama, aspek paradigma pembangunan sebelum reformasi meletakkan paradigma pembangunan yang sentralistik kemudian sekarang mengarah pada paradigma pembangunan yang terdesentralisasi. Kedua, aspek ideologi dan politik, ideologi dan politik pembangunan dapat dilihat dari aspek kebijakan politik pembangunan mengalami pola pola divergen (jamak). Perubahan ini terjadi karena diindikasikan terdapat orientasi ideologis dan politik yang berkembang di tingkat kekuasaan khususnya penguasa yang mengalami perubahan setiap 5 tahun sekali dan 10 tahun sekali paling lama. Pembatasan kekuasaan presiden hanya untuk satu kali masa jabatan sebagaimana diatur dalam UUD 1945 pasal 7 bahwa "Presiden dan Wakil Presiden memegang jabatan selama lima tahun, dan sesudahnya dapat dipilih kembali dalam jabatan yang sama, hanya untuk satu kali masa jabatan”. Kondisi ini telah membawa arah dan orientasi ideologi politik negara mengikuti arah dan orientasi ideologi politik penguasa. Apabila membahas ideologi negara tentu merujuk pada Pancasila. Pancasila menjadi ideologi negara.
Penelitian tentang ideologi dan politik pembangunan nasional di Indonesia pada paska reformasi menarik untuk dilihat kembali karena istilah ideologi juga terjadi perdebatan dan berbagai kontestasi baik di kalangan masyarakat maupun akademisi. Ideologi sebagai cita-cita, harapan, pandangan, gagasan, dan tersusun sistematis dalam bentuk tatanan nilai dan keyakinan.[1] Dalam aspek pembangunan terdapat tiga faktor utama yang mengubah paradigma pembangunan di suatu negara, yaitu: perubahan ideologi, revolusi dan inovasi teknologi dan perubahan lingkungan internasional.[2] Berbeda dengan pandangan Warjio yang melihat bahwa gagasan pembangunan merupakan kebijakan publik yang lahir dengan melibatkan banyak pihak mulai dari aktor lokal, nasional dan internasional. Keberadaan konsepsi tentang pembangunan merupakan hasil proses politik dan memiliki kepentingan yang didesain dan memiliki perencanaan untuk jangka waktu tertentu.[3] Untuk itu, pembangunan selalu berkaitan dengan aktor, proses politik, dan kepentingan tertentu. Aktor pembangunan yang penting dan berpengaruh dalam suatu negara adalah penguasa. Siapa penguasa dan memiliki peran apa? Ia akan menjadi leading sector dalam menggerakkan ideologi dan politik pembangunan pada suatu negara.

Nawacita merupakan gagasan yang menarik pada masa pemerintah Jokowi. Daya tarik istilah Nawacita ini telah mengantarkan Jokowi menjadi presiden untuk periode pertama tahun 2014 melalui pemilihan presiden secara langsung. Nawacita menjadi ideologi politik yang menarik dalam konteks pembangunan karena selama paska reformasi arah dan orientasi pembangunan masih mencari format dan bentuk. Namun pada era kepemimpinan Presiden Joko Widodo, arah dan orientasi pembangunan berpijak pada ideologi Pancasila. Presiden Joko Widodo menyebutkan bahwa "Konsep Nawa Cita dan prioritas pembangunan nasional sudah sejalan dengan komitmen tujuan pembangunan yang berkelanjutan. Yang perlu kita lakukan adalah menjalankan prioritas nasional secara baik dan efektif." (kutipan Presiden Joko Widodo, Simpul Perencana, Volume 29, Tahun 14 April 2017,hal.7). Pandangan lain menjelasan tentang ideologi pembangunan melihat bahwa ideologi pembangunan Indonesia Penelitian ini bertujuan untuk mendeskripsikan dan menggali relasi dan kontekstualisasi Nawacita, Pancasila dalam ideologi politik pembangunan nasional yang berkeadilan sosial. Keadilan sosial yang dimaksud ialah bagaimana mengurangi kesenjangan sosial dan ketidakadilan dalam pembangunan nasional untuk mendapatkan hasil hasil pembangunan yang merata. Djiwandono menjelaskan keadilan secara umum dapat dipahami sebagai suatu prinsip, norma, atau sikap, yang menuntut persamaan.[3] Batasan dalam penelitian ini akan memfokuskan pada wacana ideologi politik Pembangunan paska reformasi 
khususnya pada era pemerintahan Jokowi periode tahun 2014-2019 dan periode 2019-2024.

Penelitian ini mencoba akan menjawab persoalan penelitian sebagai berikut:1). Bagaimana konsepsi dan praktek Nawacita diterjemahkan dalam ideologi politik pembangunan? 2). Sampai sejauh mana posisi dan relasi Nawacita dan Pancasila dapat menjadi ideologi politik pembangunan di Indonesia? 3). Bagaimana tantangan praktek Nawacita dalam ideologi politik pembangunan nasional di Indonesia?

\section{B. METODE PENELITIAN}

Penelitian ini merupakan penelitian kualitatif. Sumber data penelitian ini diperoleh dari dokumen kebijakan pemerintah, peraturan perundang undangan, laporan penelitian, jurnal, buku yang relevan dengan penelitian. Data yang diperoleh kemudian dikategorisasikan untuk dilakukan pemilihan kesesuaian dengan topik penelitian. Analsis data menggunakan reduksi data, interpretasi dan analisis kebijakan.

\section{HASIL DAN PEMBAHASAN}

\section{Konsepsi Nawacita dan pembangunan nasional}

Asal mula konsepsi Nawacita dapat ditelusuri dalam kontestasi pemilihan calon presiden dan wakil presiden Republik Indonesia. Nawacita merupakan salah satu tawaran Joko Widodo saat mencalonkan diri menjadi calon presiden dan wakil presiden 2014. Salah satu agenda dan kampanye politik yang diwacanakan oleh Joko Widodo ialah Nawacita dengan "menghadirkan kembali negara", "membangun dari pinggiran", dan "gerakan revolusi mental".

Nawacita adalah ideologi. Jejak jejak Nawacita sebagai ideologi secara tidak langsung dapat ditemukan pada dokumen yang diterbitkan oleh Kementerian Perencanaan Pembangunan Nasional/ Badan Perencanaan Pembangunan Nasional, 2014 yang diberi judul "Buku I Agenda Pembangunan Nasional, Rencana Pembangunan Jangka Menengah Nasional 2015-2019". Dalam penjelasan bab buku ini menguraikan tentang meneguhkan kembali jalan ideologis.

Ideologi dalam dokumen ini diterjemahkan sebagai penuntun; ideologi sebagai penggerak; ideologi sebagai pemersatu perjuangan; dan ideologi sebagai bintang pengarah. Ideologi itu adalah Pancasila.[4] Dalam kehidupan bernegara, pemerintah perlu mengambil kebijakan pembangunan dalam upaya melakukan perubahan yang lebih baik bagi warganya. Dalam upaya realisasi untuk menjaga keseimbangan sistem kenegaraan. Pemerintah memiliki peran penting dalam menjalankan mekanisme pembangunan.[5] Secara konseptual, konteks pembangunan nasional dapat dijelaskan bahwa Pembangunan nasional yang dibuat oleh negara pada hakikatnya merupakan usaha mewujudkan keadilan sosial dalam berbagai bidang kehidupan. Kondisi ini dapat diartikan sebagai suatu usaha transformasi total dari pola kehidupan tradisional kepada pola kehidupan modern sesuai dengan kemajuan jaman serta didukung oleh ilmu pengetahun dan teknologi untuk mencapai cita cita dan tujuan bernegara.[6] Secara yuridis, konsep pembangunan nasional dapat dilihat dari Undang Undang Nomor 17 Tahun 2007 tentang Rencana Pembangunan Nasional Jangka Panjang Nasional Tahun 2005-2025 dalam klausul menimbang poin $\mathrm{b}$ menjelaskan bahwa "Indonesia memerlukan perencanaan pembangunan jangka panjang sebagai arah dan prioritas pembangunan secara menyeluruh yang akan dilakukan secara bertahap untuk mewujudkan masyarakat adil dan makmur sebagaimana diamanatkan oleh Undang-Undang Dasar Negara Republik Indonesia Tahun 1945”. Dalam Undang Undang Nomor 25 Tahun 2004 tentang Sistem Perencanaan Pembangunan Nasional pada pasal 1 ayat (2) menjelaskan bahwa "Pembangunan Nasional adalah upaya yang dilaksanakan oleh semua komponen bangsa dalam rangka mencapai tujuan bernegara". bertitik tolak pada definisi ini aspek perencanaan pembangunan nasional menjadi untuk untuk diterjemahkan menjadi jalan ideologis pembangunan nasional.

Jalan ideologis pembangunan berpijak pada konsepsi Nawacita. Nawacita menjadi ideologi politik pembangunan nasional pada masa kepemimpinan Jokowi. Sejak reformasi 1999 sampai sekarang, arah dan orientasi politik pembangunan nasional memiliki format yang mengarah pada ideologi Pancasila. Berbeda dengan pemerintahan sebelumnya, penegasan secara ideologis dalam politik pembangunan nasional tidak terlalu menjadi perhatian dari para pemimpin nasional. Agenda Nawacita yang dimaksud sebagai berikut:

Tabel 1

Nawacita

\begin{tabular}{cl}
\hline No & \multicolumn{1}{c}{ Deskripsi } \\
\hline 1 & $\begin{array}{l}\text { Menghadirkan kembali negara untuk melindungi segenap } \\
\text { bangsa dan memberikan rasa aman pada seluruh warga } \\
\text { negara }\end{array}$ \\
2 & $\begin{array}{l}\text { Membuat pemerintah tidak absen dengan membangun tata } \\
\text { kelola pemerintahan yang bersih, efektif, demokratis, dan } \\
\text { terpercaya. }\end{array}$ \\
3 & $\begin{array}{l}\text { Membangun Indonesia dari pinggiran dengan memperkuat } \\
\text { daerah-daerah dan desa dalam kerangka negara kesatuan }\end{array}$ \\
4 & $\begin{array}{l}\text { Menolak negara lemah dengan melakukan reformasi sistem } \\
\text { dan penegakan hukum yang bebas korupsi, bermartabat, } \\
\text { dan terpercaya }\end{array}$ \\
5 & $\begin{array}{l}\text { Meningkatkan kualitas hidup manusia Indonesia. } \\
\text { Meningkatkan produktivitas rakyat dan daya saing di pasar } \\
\text { internasional }\end{array}$ \\
7 & $\begin{array}{l}\text { Mewujudkan kemandirian ekonomi dengan menggerakkan } \\
\text { sektor-sektor strategis ekonomi domestik }\end{array}$ \\
8 & $\begin{array}{l}\text { Melakukan revolusi karakter bangsa. } \\
\text { Memperteguh kebhinekaan dan memperkuat restorasi sosial } \\
\text { Indonesia }\end{array}$ \\
\hline
\end{tabular}

Sumber: Visi-Misi Jokowi-JK, 2014.[7] 
Berdasarkan tabel 1 di atas menunjukkan bahwa konsepsi dari Nawacita meletakkan nilai nilai dasar pada cita-cita dan tujuan nasional. Pemikiran ini juga mengadopsi dari gagasan Soekarno tentang Trisakti Pancasila. Ideologi politik pembangunan yang diletakkan pada masa presiden Soekarno tentang pembangunan semesta dan Trisakti Pancasila yang membangun jargon "berdaulat di bidang politik", berdikari di bidang ekonomi', dan berkepribadian dalam kebudayaan", menjadi kata kunci penting dalam pembentukan ideologi politik pembangunan. Undang undang No. 17 Tahun 2007 tentang Rencana Pembangunan Jangka Panjang Nasional tahun 20052025 menetapkan bahwa visi pembangunan nasional adalah untuk mewujudkan Indonesia Yang Mandiri, Maju, Adil dan Makmur. Dalam konteks visi tersebut aspek aspek Mandiri, Maju, Adil, dan Makmur dimaknai dan diuraikan sebagai berikut:

Mandiri: berarti mampu mewujudkan kehidupan sejajar dan sederajat dengan bangsa lain dengan mengandalkan pada kemampuan dan kekuatan sendiri. Maju: berarti tingkat kemakmuran yang tinggi disertai dengan sistem dan kelembagaan politik dan hukum yang mantap. Adil: berarti tidak ada pembatasan/diskriminasi dalam bentuk apapun, baik antar individu, gender, maupun wilayah. Makmur: berarti seluruh kebutuhan hidup masyarakat Indonesia telah terpenuhi sehingga dapat memberikan makna dan arti penting bagi bangsa-bangsa lain.[6]

Nawacita sebagai ideologi politik pembangunan menjadi kajian yang menarik dari beberapa akademisi. Penelitian yang dilakukan oleh Murdiyana dan Mulyana menjelaskan bahwa ketika presiden Joko Widodo Menjabat terdapat beberapa program pembangunan di dalam Nawacita yang pro pada upaya pengentasan kemiskinan. Program tersebut disebutkan dalam 9 agenda prioritas pembangunan yang disebut Nawacita yaitu: 1. membangun Indonesia dari pinggiran dengan memperkuat daerah-daerah dan desa dalam kerangka negara kesatuan; 2.meningkatkan kualitas hidup manusia Indonesia. Pada pemerintahan Joko Widodo dan Jusuf Kalla, garis ideologi politik pembangunan untuk mewujudkan keadilan sosial secara khusus untuk penanggulangan kemiskinan melalui 4 strategi yaitu:(1) Memperbaiki program perlindungan sosial; (2) Meningkatkan akses terhadap pelayanan dasar; (3) Pemberdayaan kelompok masyarakat miskin; (4) Menciptakan pembangunan yang inklusif.[6]. Lainnya mendeskripsikan program dana desa atau yang disebut (village fund) sebagai bentuk dan upaya implementasi Nawacita. Hasil dari penelitian Nurpuspita, Sarfiah dan Ratnasari menunjukkan bahwa dana desa yang dikelola dengan baik dapat mendukung dalam upaya percepatan pembangunan di desa dengan meningkatkan partisipasi masyarakat melalui peningkatan pelayanan masyarakat, memajukan perekonomian desa, mengatasi kesenjangan pembangunan antar desa dan penguatan desa untuk kesejahteraan masyarakat di desa. Alokasi dana desa digunakan untuk pembangunan infrastruktur mendukung perekonomian dan pemberdayaan masyarakat.[8]

Penelitian yang dilakukan oleh tim peneliti dari Sekretariat Jenderal DPR RI tentang Nawacita dalam upaya perwujudan dan percepatan pembangunan nasional yang berkeadilan sosial menguraikan bahwa program Nawacita menekankan pada kemandirian, kedaulatan pada sektor sektor strategis nasional dan pemberdayaan masyarakat telah diuraikan pembahasan secara khusus dalam beberapa bagian yaitu:Pada bagian pertama membahas tentang daya saing produk pangan lokal, kemandirian sektor pertanian, menjamin kedaulatan keuangan nasional, peningkatan produktivitas rakyat dan daya saing bangsa, meningkatkan kualitas hidup manusia, pembangunan sektor perikanan laut, perlindungan dan pemberdayaan nelayan miskin, dan mendukung Pegawai Negeri Sipil yang taat terhadap waktu kerja.[9]

Dinamika pembangunan di Indonesia banyak berbicara pada pembangunan politik dan ekonomi. Pola pola pembangunan yang kecenderungan dibangun selama 2 dekade terakhir membahas pembangunan politik dan ekonomi. Untuk itu, memotret dan menelusuri arah pembangunan nasional dapat diilakukan melalui praktek praktek politik pembangunan yang selama ini dijalankan oleh pemerintah Indonesia pada masa paska reformasi. Praktek politik pembangunan yang selama ini dilakukan ialah pada periode paska reformasi dapat ditunjukkan pada jejak jejak kepemimpinan Abdurahman Wahid (Gusdur), ketika Gusdur menjadi presiden Republik Indonesia periode 1999-2001, kebijakan yang penting dalam meletakkan paradigma pembangunan ialah menggeser paradigma pembangunan yang berbasis daratan mengarah pada paradigma pembangunan yang berbasis kelautan dan kemaritiman. Salah salah satu langkah atau program yang dibuat Gusdur secara kelembagaan dan struktural mendirikan departemen eksplorasi laut. Kemudian pada tahun 2005 diubah menjadi kementerian keluatan dan perikanan.[10] Pada masa kepemimpinan Presiden Megawati Soekarnoputri, kebijakan dan arah politik pembangunan nasional meletakkan pada stabilitas ekonomi.

Dinamika politik ekonomi pada awal paska reformasi menjadikan pembangunan nasional secara umum terbengkalai. Presiden Megawati melalui kabinet gotong royong berbagai kebijakan pemerintah untuk mendukung pembangunan menekankan pada upaya memperbaiki sektor ekonomi dengan beberapa agenda antara lain restrukturisasi dan reformasi sektor keuangan, meningkatkan kegiatan ekspor, menciptakan situasi kondusif bagi investor, mendorong kemajuan usaha kecil dan menengah, dan meningkatkan 
pemanfaatan sumber daya laut. Sedangkan pada masa pemerintahan Susilo Bambang Yudhoyono, melalui kabinet Indonesia bersatu I dan II lebih banyak menekankan paradigma pembangunan yang berbasis investasi, mencabut berbagai subsidi termasuk subsidi BBM, melakukan program Bantuan Langsung Tunai (BLT) (Dokumen Kementerian Kelautan dan Perikanan Republik Indonesia, tanpa tahun). Selain itu terdapat program menghapus minyak tanah dikonversikan menjadi program elpiji tabung $5 \mathrm{~kg}$. Dinamika politik pembangunan nasional di Indonesia banyak menekankan pembangunan sektor ekonomi dan politik.

\section{Posisi dan relasi Nawacita dan Pancasila dalam ideologi politik pembangunan di Indonesia}

Ideologi pembangunan pada dasarnya mengalami krisis. Krisis tersebut telah diuraikan oleh Hadar dalam tulisannya pada harian Seputar Indonesia berjudul Ideologi pembangunan. Menurut Hadar terjadinya krisis ideologi pembangunan berakar dari krisis teori pembangunan. Teori pembangunan selama ini dilihat hanya pada dua kutub yaitu kutub modernisasi dan kutub dependensi. Paradigma pembangunan yang berjalan mengejar pertumbuhan dan kemajuan dengan cara meletakkan filosofi modernisasi akan berimplikasi pada kebijakan kebijakan politik pembangunan yang mengarah pada efesiensi dan capital serta teknologi. Sedangkan paradigma yang mengedepankan dependensi melihat posisi negara negara dalam posisi berkembang dan terbelakang. Berbagai utopia dan model teori pembangunan yang berkembang selama ini telah membawa jebakan dalam mempraktekkan pembangunan pada ranah ekonomi semata. Menurut Hadar bahwa "Pancasila, sebagai ideologi dan orientasi pembangunan yang cukup lama terbengkalai, sebenarnya memberikan ruang yang luas dalam mengupayakan pembangunan berkeadilan, baik bagi bangsa Indonesia maupun masyarakat global”. [11]

Pancasila merupakan dasar negara Indonesia yang sudah seharusnya menjadi dasar dan pedoman dalam perencanaan dan pelaksanaan pembangunan nasional dalam segala bidang. Namun, Pancasila sebagai dasar negara masih belum secara maksimal dipraktekkan dalam kehidupan bernegara. Kedudukan dan fungsi Pancasila selama ini masih sebatas dalam konteks meletakkan dasar dasar bernegara tetapi aplikasi dan operasionalisasi Pancasila sebagai dasar negara belum dijalankan dengan baik oleh penyelenggara negara. Darmodiharjo dan Shidarta menjelaskan bahwa hakikat Pancasila merupakan nilai dan mengandung kualitas tertentu. Prinsip prinsip dasar yang mengandung kualitas tertentu itu merupakan cita cita dan harapan atau akan dituju oleh bangsa Indonesia untuk diwujudkan dalam kenyataan dalam kehidupan pribadi, bermasyarakat, berbangsa dan bernegara.[12]
Kajian Bahar menjelaskan bahwa Pancasila telah menjadi dasar paradigma pembangunan nasional, artinya bahwa Pancasila dirumuskan sebagai pembentukan penyelenggaraan negara. Pancasila sebagai dasar paradigma pembangunan nasional diarahkan dalam bentuk landasan dan dasar dalam penyusunan kebijakan pembangunan nasional di Indonesia.[12] Hanum juga lebih lanjut menjelaskan bahwa makna Pancasila sebagai paradigma pembangunan nasional mencakup perihal pembangunan ekonomi, iptek, dan pendidikan.[13]

Selama ini, politik pembangunan masih meletakkan politik pembangunan ekonomi dan politik. Dalam menerapkan politik dan ideologi pembangunan nasional masih belum jelas dasar pijakan ideologis yang diletakkan dalam politik pembangunan nasional. Posisi Pancasila perlu kembali dipertegas dalam kerangka berbangsa dan bernegara khususnya dalam praktek. Dalam 2 dekade terakhir, politik pembangunan nasional di Indonesia masih diwarnai pada politik pembangunan yang meletakkan pada paradigma ekonomi pasar dan developmentalism. Paradigma pembangunan berpijak pada ekonomi pasar menekankan bahwa pro-growth, pro-poor, dan pro-job. Jargon politik pembangunan berpijak pada ekonomi pasar merupakan pra syarat dalam era global. Kondisi yang harus dipenuhi ialah persoalan efesiensi dan produktivitas, persaingan/kompetisi, dan alokasi sumber daya yang kompeten dan profesional untuk memacu pembangunan, serta mengharapkan peran pemerintah yang minimalis. Pada konteks yang lain, paradigma pembangunan yang berpijak ideologi pembangunan global menekankan pada pembangunan yang berbasis ekologis, etis, dan populis. Selama ini negara Indonesia mengikuti kedua arus tersebut.

Format pembangunan nasional mulai mengarah pada upaya meletakkan dasar ideologis yang berpijak pada Pancasila dimulai dari kepemimpinan Joko Widodo. Gagasan pembangunan harus memiliki acuan ideologis yang jelas menjadi cita cita presiden Joko Widodo untuk meletakkan ideologi politik pembangunan dalam satu kesatuan yang utuh. Menghadirkan kembali negara, membangun dari pinggiran, revolusi karakter, menolak negara lemah, dan meningkatkan kualitas sumber daya manusia, serta mewujudkan kemandirian ekonomi menjadi filosofi pembangunan dalam aspek ideologi dan politik pembangunan nasional dalam agenda Nawacita. Latif menjelaskan bahwa pembangunan nasional pada hakikatnya merupakan gerak berkelanjutan dari peningkatan mutu budaya dan peradaban dalam rangka mewujudkan cita cita nasional berlandaskan kerangka (keyakinan, pengetahuan, dan tindakan) Pancasila.[14]

Nawacita sebagai upaya untuk menerjemahkan Pancasila sebagai dasar negara menjadi dasar dan pedoman dalam membangun politik dan ideologi 
pembangunan nasional. Relasi antara Pancasila dan Nawacita dapat ditunjukkan dari nilai nilai yang ditawarkan dari Nawacita dan Pancasila. Pancasila yang terdiri atas 5 sila memiliki nilai dan prinsip prinsip yang hendak diwujudkan dalam suatu negara serta dijamin oleh negara agar dapat terlaksana dengan baik sesuai dengan cita cita dan tujuan bernegara. Pancasila menjadi landasan idiil dalam membangun dan membentuk format dasar pembangunan nasional dan Nawacita menjadi kerangka kebijakan untuk melaksanakan pembangunan nasional. Dalam Peraturan Presiden Republik Indonesia Nomor 2 Tahun 2015 Tentang Rencana Pembangunan Jangka Menengah Nasional Tahun 2015 - 2019, Pasal 2 ayat (1) menyebutkan bahwa RPJM Nasional merupakan penjabaran dari visi, misi dan program Presiden hasil Pemilihan Umum tahun 2014. Untuk itu, ideologi politik pembangunan pada periode 2014 sampai sekarang menerjemahkan visi, misi dan program Presiden hasil Pemilihan Umum tahun 2014. Pada tahun 2014, Jokowi terpilih sebagai Presiden Republik Indonesia dengan mengangkat agenda Nawacita. Nawacita ini telah mewarnai paradigma pembangunan nasional di Indonesia yang memiliki dasar dasar ideologi Pancasila.

\section{Tantangan praktek Nawacita dalam ideologi politik pembangunan nasional di Indonesia}

Nawacita sebagai landasan dalam praktek pembangunan nasional yang telah diletakkan oleh presiden Joko Widodo pada tahun 2014 sampai sekarang mengalami kemajuan yang melambat. Pada awal gagasan ini dideklarasikan dan menjadi dasar ideologi dan politik pembangunan nampak berbagai perubahan kebijakan di negara Indonesia khususnya dalam pembangunan politik, ideologi, dan kerja kerja pemerintahan. Percepatan pembangunan di daerah daerah pedalaman, perbatasan, dan pulau pulau terluar menjadi perhatian penting dalam pemerintahan periode pertama presiden Joko Widodo. Namun, dalam perkembangannya, praktek Nawacita mendapatkan tantangan baik dari aspek internal dan eksternal.

Upaya untuk mewujudkan negara kuat dan hadir dalam segala aspek kehidupan masyarakat tidak semudah yang dibayangkan dan imajinasikan. Tantangan internal yang sampai sekarang ini belum secara penuh dapat terselesaikan terkait reformasi birokrasi dan budaya kerja birokrasi. Aparatus negara memiliki peran penting dalam mempercepat proses pembangunan nasional di Indonesia. Nawacita sebagai landasan kerja dan berpikir tidak akan dapat berjalan dengan baik tanpa ada dukungan budaya kerja dan mentalitas apparatus negara dalam menjalankan fungsi fungsi kerja kelembagaan dan struktural. Catatan lainnya memberikan penjelasan bahwa tantangan terbesar dari pelaksanaan Nawacita berada pada aparat dan budaya kerja birokrasi.[2][15]

\section{SIMPULAN DAN SARAN}

Penelitian tentang Nawacita, Pancasila, dan Ideologi politik pembangunan di Indonesia menunjukkan bahwa selama ini arah ideologi politik pembangunan sejak paska reformasi masih diwarnai pada dua paradigma utama yaitu paradigma global dan paradigma ekonomi. Dalam perkembangannya, paradigma pembangunan dari aspek ideologi dan politik pembangunan pada masa kepemimpinan Presiden Joko Widodo telah menegaskan bahwa ideologi politik pembangunan nasional di Indonesia berlandaskan pada visi, misi dan program kerja Presiden melalui agenda Nawacita. Nawacita merupakan bentuk terjemahan pengamalan nilai nilai Pancasila dalam bentuk pembangunan nasional yang menekankan pada pentingnya kehadiran negara dalam mewujudkan keadilan sosial, menolak negara lemah, membangun dari pinggiran, dan meningkatkan kualitas sumber daya manusia. Kata kunci ini yang menjadikan Nawacita memiliki relasi dengan Pancasila dari aspek ideologi dan politik pembangunan nasional. Kedepannya penelitian selanjutnya dapat menganalisis seberapa efektif 10 tahun atau 2 periode kepemimpinan Presiden Joko Widodo dalam melaksanakan Nawacita.

\section{UCAPAN TERIMA KASIH}

Penelitian ini merupakan bagian dari hibah penelitian dasar yang diselenggarakan oleh Lembaga Penelitian dan Pengabdian Kepada Masyarakat Universitas Pembangunan Nasional "Veteran" Yogyakarta tahun 2020. Peneliti mengucapkan terima kasih atas dukungan dari LPPM UPN "Veteran" Yogyakarta.

\section{DAFTAR RUJUKAN}

[1] M. I. Rahmat, Ideologi Politik PKS; Dari Masjid Kampus ke Gedung Parlemen. LKIS PELANGI AKSARA, 2008.

[2] S. S. Syamsi, "Nawa Cita Jokowi-JK dalam Paradigma Pembangunan Ekonomi," Surya Octag. Interdiscip. J. Sci. Technol., vol. 1, no. 1, pp. 73-102, 2015.

[3] J. S. Djiwandono, Setengah abad negara Pancasila: tinjauan kritis ke arah pembaruan. Centre for Strategic and International Studies, 1995.

[4] B. P. P. Nasional, "Direktorat Pangan dan Pertanian Kementerian Perencanaan Pembangunan Nasional: Jakarta Pusat," 2014.

[5] A. R. bin Mawazi and R. P. Hidayatulah, "Islam dan Ideologi dalam Pembangunan di Indonesia: Studi Terhadap Program Nawacita,” Anal. J. Stud. Keislam., vol. 18, no. 2, pp. 171-188, 2018.

[6] M. Murdiyana, "Analisis Kebijakan Pengentasan Kemiskinan Di Indonesia,” J. Polit. Pemerintah., vol. 10, no. 1, pp. 73 - 96, 2017.

[7] S. B. Ilkodar, L. Budiman, and H. Hastangka, "Pemetaan Model Pembelajaran Pancasila Pada Perguruan Tinggi Di Daerah Istimewa Yogyakarta," CIVIS, vol. 9, no. 1, 2020. 
[8] R. Nurpuspita, S. N. Sarfiah, and E. D. Ratnasari, "Analisis Pengelolaan Dana Desa Sebagai Realisasi Salah Satu Tujuan Program Nawacita 'Membangun Indonesia Dari Pinggiran' Di Kecamatan Bener Kabupaten Purworejo Tahun 2016," Din. Dir. J. Econ., vol. 1, no. 2, pp. 136-150, 2019.

[9] D. dkk Wuryandani, "Mewujudkan Agenda Prioritas Nawacita," P3DI Setjen DPR RI dan Azza Graf., 2015.

[10] D. R, "Gusdur Kembalikan Dasar Pembangunan Ekonomi yang Awalnya Berorientasi Darat menjadi Laut," Tribun.com, 2019.

[11] Hadar.I., "Ideologi Pembangunan," nasional.sindonews.com, 2014.

[12] S. Bahar, "Pancasila Sebagai Paradikma Pembangunan Nasional Bidang Sosial Politik," J. Ketahanan Nas., vol. 6, no. 2001, 2001.

[13] F. Hanum, "Pendidikan Multikultural Dalam Pluralisme Bangsa," Pap. Accessed March 29, 2012, 556 PM from http//eprints.uny.ac.id/3968/1/PENDIDIKAN_MUL TIKULTURAL_DALAM_PLURALISME_BANGSA.pdf ., pp. 1-24, 2011.

[14] L. Y., Wawasan Pancasila Edisi Komprehensif. Mizan, 2020.

[15] M. W. Saragih, "Relevansi Konsep Trisakti Soekarno dengan Nawacita Pemerintahan Jokowi-JK." 